\title{
Renáta MAROSI
}

\section{Developing cognitive and language skills through visual arts}

\section{Introduction}

The selection of the research topic has been inspired by an informal pedagogical observation made at the Department of English Language and Literature of J. Selye University in Slovakia between 2016 and 2020. The following chapters intend to find a theoretical background of this pedagogical experience. The aforementioned observation was taking place in various first-year courses that sought to improve teacher trainees' language skills (on language seminars) and expand their knowledge on British cultural and historical studies. Two main observations have occurred. Firstly, students have difficulties in expressing themselves when they have to justify their choice of English tenses even if they are perfectly aware and certain of the proper use of grammatical structures. As it caused difficulties even to students with appropriate English language level, it cannot be stated that the reason for the students' inability to express themselves was (only) related to their language level. Secondly, in the course 'The Culture and History of Great Britain', they could hardly search for (symbolical) details and connections with regard to a particular Victorian painting, for they were not accustomed to working with exercises on visual arts. However, once the first hints and clues were revealed for the sake of interpretation, they felt motivated to continue the work.

"The use of arts in other subjects will make it possible to teach students more coherently and effectively" (Csehiová 2014, 59). Therefore, by bringing visual arts-based tasks to the EFL classroom, students' cognitive skills can be developed, and Eventually this method could contribute to successful self-expression, including both formulating students' own opinions and justifying the proper use of English grammar (e.g. Why am I using this tense? Why are both tenses acceptable in this sentence? Why is this tense incorrect here?). This pedagogical approach could even reduce students' uncertainty and increase the level of consciousness in the use of English grammar (e.g. I do not know why I chose this tense. It was just a feeling. I chose this one because it sounds better, etc.). Of course, language teachers should not forget that a successful learning process demands both cognitive and language skills; thus, both should be developed simultaneously. By the aforementioned tasks, students start intensively using not only their own imagination but also their cognitive critical thinking skills: they start seeing and making connections, asking question looking beyond' (i.e. observe painting as a coherent text including its explicit and implicit details). Undoubtedly, the ability to make connections and reasoning is essential in (second) language learning. The following chapters, on the one hand, give the reader a brief overview of how and why one can develop cognitive skills in EFL education through visual arts. On the other hand, the reader will receive information and suggestion about the possible use of paintings in EFL education by describing a visual arts-based lesson plan.

\section{Developing Critical Thinking Skills in EFL Education}

"Teaching visual culture is about students making and viewing the visual arts to understand their meanings, purposes, relationships, and influences" (Freedman 2003: 11). For the purpose of unveiling these aspects and relations, developing students' ways of thinking is a must. Working with arts requires a high(er) level of cognitive skills, of which critical thinking is an essential component. The experts include the following as being at the very core of critical thinking: "interpretation, analysis, evaluation, inference, explanation, and self-regulation" (Facione 2020: 5). L2 acquisition likewise demands the aforementioned elements: to interpret and analyze rules (e.g. tenses, syntax, morphology) and to consciously and properly use them, which process can be consistent with inference, self-regulation and evaluation. Scriven and Paul further defined critical thinking in the following way:

"Critical thinking is the intellectually disciplined process of actively and skilfully conceptualizing, applying, analyzing, synthesizing, and/or evaluating information gathered from, or generated by, 
observation, experience, reflection, reasoning, or communication, as a guide to belief and action. In its exemplary form, it is based on universal intellectual values that transcend subject matter divisions: clarity, accuracy, precision, consistency, relevance, sound evidence, good reasons, depth, breadth, and fairness. To think critically entails having command of such standards." (Eutsler 2017: 34). Further, Eutsler (2017) explains that teachers' questions to students activate this skill, "which then guides them to better and better reasoning" (34-35). Among these questions enumerated in his research, the following ones might be considered beneficial from the point of view of the present study. The questions - that are proper both for the analysis of a painting and interpreting any phase of the language learning process - were adapted to a possible grammar discussion (see them is brackets): Could you give me an example? (clarity; e.g. giving an example of a sentence in the present continues); How could we find out if that is true? (accuracy; e.g. in True or False exercise); Could you be more specific? (precision; e.g. in justifying his/her choice of the selected tense); How is that connected to the question? (relevance; i.e. to understand the theory and use it in practice); How are you taking into account the problems in the question? (depth; e.g. which particular rule makes you choose the present continuous?); Is there another way to look at this question? (breadth; i.e. to recognize that more tenses are acceptable at the same time or to study homophones and homographs); Does this really make sense? (logic; e.g. to check correct word order, to choose the word that fits best in the context).

It is also worth noting that besides asking questions, "[p]rominent theories of cognitive development [e.g. Vygotsky, Luria, Gagne] would further suggest that thinking is [also] greatly influenced by instruction" (Baker 2013: 5). Therefore, giving the appropriate instruction is as important as asking relevant questions in order to guide students' way of thinking. Even Peterson suggests that teachers are able to influence students' world views through elements of behaviour such as "making comparisons, viewing things from different perspectives, looking for ways to remember information, and recalling information" (Peterson 2005; Baker 2013: 5). These elements are also highly similar to Eutsler's elements of reasoning: "purpose, question, information, inference, assumption, point of view, concepts, and implications" (Eutsler 2017: 37). It is because "most conventional instruments of cognitive and intellectual functioning have elements of reasoning, conceptual and abstract thinking, patterns and relationships, quantitative elements, vocabulary, retrieval, and/or visual-spatial recognition" (Baker 2013: 6). In a word, it can be pointed out that (second language) learning is a combined and complex process of memorizing, recalling, synthesizing, reasoning and concluding.

\section{Visual Arts in (EFL) Education}

Using visual arts in (second) language acquisition is likewise a complex process because it links the hemispheres of the brain: the left that is "specialized not only for language but also for analytical and sequential thinking" and the right that is responsible "for spatial thinking and visuomotor skills" (Silver 1989: 10). However, it is still worth making a permeable and deliberate connection between them as "[l]ike language symbols, art symbols are a way of labelling perceptions and imagining experiences. They can represent particular subjects or classes of subjects." (Silver 1989: 6) Furthermore, arts provide various competencies "in developing cognitive growth, including the perception of relationships and that problems and questions can have multiple possibilities" (Baker 2013: 2).

Generally speaking, using visual aids in education is a globally-acknowledged pedagogical method nowadays. A teacher can help students acquire and memorize new words in the following way: by using 'realia,' which means that the teacher holds up various objects or "points to it, says the word and then gets students to repeat it" (Puskás 2018: 56); bringing pictures into the classroom; using digital technology and portable devices such as "the Internet, the interactive whiteboard, tablets and smartphones" (Puskás 2018: 57); describing pictures; etc. Of course, when using visual aids, many factors must be considered in order to use them effectively and successfully: their relevance in connection with the curriculum, the student's age and language level, the students' learning abilities, the classroom equipment and technical background, etc. Interestingly, "[s]ince materials which are based on multimedia seem to attract students' attention more than the conventional materials used 
in the traditional teaching methods (printed handouts, realia, flashcards), using audiovisual media might be a fruitful approach" (Zolczer 2016: 117).

As far as the further relevance of using visual materials in education is concerned, "[w]e all communicate visually in the many social situations of our everyday lives [...] Given the importance of visual communication in real life, discussing the role of the visual in educating the next generation is a task that needs to be confronted by teachers" (Havé 2013: 7). As for its importance in TEFL, "[b]eing able to describe what one sees is one of the basic skills one has to train when learning a language" (Havé 2013: 8). Indeed, for example, picture description is one of the most common exercises to practice the present continues, and it is one of the tasks of the school-leaving English exam and in language exams (at least in Slovakia and Hungary). More to the point, "[t]he requirements of modern education are met by subjects that which have a multifaceted effect" (Csehiová 2014, 67). In this sense, as Gower et al. (2005) state, visuals "attract the students' attention and aid concentration", and they "add variety and interest to a lesson" but also "help to make the associated language memorable" (70-71). Furthermore, as far as possible use of (English) video-game, as audio-visual aids, in EFL education is concerned, a story-based (or "fictional narrative-"based) video game "not only raises the intrinsic motivation," but also "the player is exposed to the language not only in written form (in the form of subtitles and captions on the screen) but also in audio form; therefore the listening and pronunciation skills can also be engaged and improved throughout gaming (as opposed to reading)" (Zolczer 2019: 233, 234). In other words, using audio-visual materials, students break with regular reading, writing and listening exercises to turn to something else that, although likewise requires their attention and concentration, also aids in maintaining their interest in the given curriculum and keep their attention and motivation.

As for the legitimacy of visual arts in improving cognitive skills, "[m]usic, the visual arts, and dance can be used to develop critical thinking, which includes the ability to use logic and reasoning in problemsolving. Critical thinking is an active, purposeful, organized, and cognitive [emphasis is mine] process that ... can be explicitly taught" (Eutsler 2017: 86). It is also "a great routine for students to learn how to reason with evidence. And it promotes independence." They work on their own while relying on the teacher for a clue. "It is a routine that can be adapted to any topic" (Brock 2018). Furthermore, wellprepared interactive visual arts-based task "makes space for their voice, makes space for their thinking" (Kullberg 2018). Arts helps students "express how they feel and think about the world [...] express the feelings and ideas that they don't have the words to talk about" (Mincemoyer 2016: 1).

\section{An Example of a Visual Arts-Based Activity}

Based on the aforementioned theoretical formulations, I assume that with regular and systematic use of visual arts-based tasks, the students' cognitive skills can be developed, which they can use in their (second) language learning process. The following part functions as an inspiration for teachers to bring paintings into (EFL) classroom. The constant use of brackets with the term 'EFL' is not a coincidence; hence the use of visual arts should not be limited to second language teaching-learning only and is highly recommended to be included in the curriculum of other subjects as well. The following lesson plan is not only meant to improve language skills but also cognitive skills; the exercises below already presuppose a B1/B2 language level. Taking into account the message of the chosen painting, the recommended age of students is between 17-19.

Topic: Augustus Leopold Egg's Past and Present - Misfortune

Age of students: 17-19

Language level of students: B1/B2

Time: 45 minutes

Aims:

- to recall and practice the proper use of the present continuous (painting description),

- to recall and practice the proper use of the present simple (expressing opinions),

- to be able to express their own opinions about the topic of the painting,

- to be able to see explicit and implicit connections in the painting (symbolic references), 
- to active cognitive skills: to reinforce concentration, critical thinking, reasoning, caution, connection making skills,

- to improve imagination and creativity.

Aids: worksheet that includes the painting (to each student), overhead projector and whiteboard Classroom management: group work; class work.

Process:

1. administration and organization (2 minutes),

2. students are given a worksheet including the selected painting along with exercises (1 min.),

3. students are given the following instruction: read a short description of the socio-historical background of the painting ( $1 \mathrm{~min}$.),

4. students are divided into groups of 3/4/5 (1 min.),

5. each group is asked to answer the questions of the painting (20 min.). They are also asked to note their thoughts down and to carefully choose tenses.

Note: teacher should ensure them not to feel embarrassed and disappointed if they cannot answer every question. The teacher also shows the painting in big size - hence the overhead projector and the whiteboard.

6. The whole class discusses the answers with teacher's guidance (20 min.)

Note: the teacher should approach the last question very carefully and warn the students that it is not compulsory to join this part of discussion if they find it uneasy.

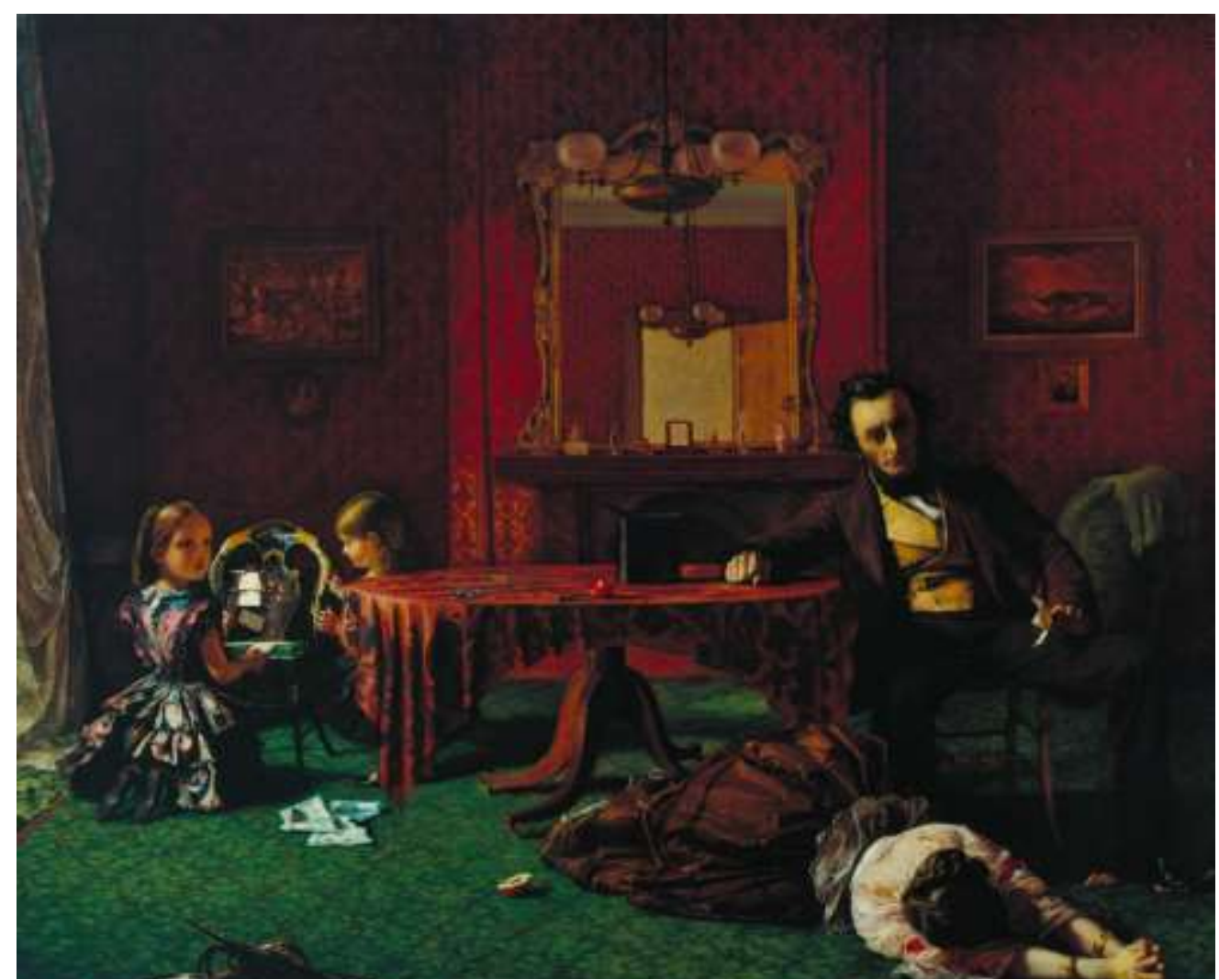

Picture 1: Augustus Leopold Egg's Past and Present - Misfortune

The painting above is Augustus Leopold Egg's work or art, who painted in the nineteenth-century Victorian England, when British people were living according to strict social norms and conventions, and when women had only a few rights. Men and women were not equally hold responsible. As Caroline Norton, an early feminist, wrote, "the faults of women are visited as sins, the sins of men are not even visited as faults." Many women and also man started fighting for more political and social rights of women. As a result, for example, by the end of the century, under particular circumstances, they were given the right to become official charges of their own children. 


\section{Study the painting carefully. Then, answer the following questions.}

Basic data:

1) In which century was the artwork painted?

2) How many people can you see in the painting?

3) What is the relationship between the people in the paining?

\section{Content:}

4) What is the woman doing?

5) What is the man doing?

6) What are the girls doing?

\section{Emotions:}

7) Look at each person's facial expression (at least whose you can see!) and describe how they might be feeling.

the man:

the older girl:

the younger girl:

8) What do their facial expression mean to you?

\section{Symbols:}

9) What family problems do you think Egg wanted to depict here? Study the title.

10) What is the husband holding in his hand?

11) Look at the women's arms. What does she want?

12) Which fruit can you recognize in the painting?

13) What does it mean that the fruit is cut in two?

14) What does the fallen apple symbolize?

15) What does the apple with a knife in it symbolize?

16) Find other scenes, clues from the painting which imply their broken marriage. Find at least three of such symbols. The pictures below might help you.

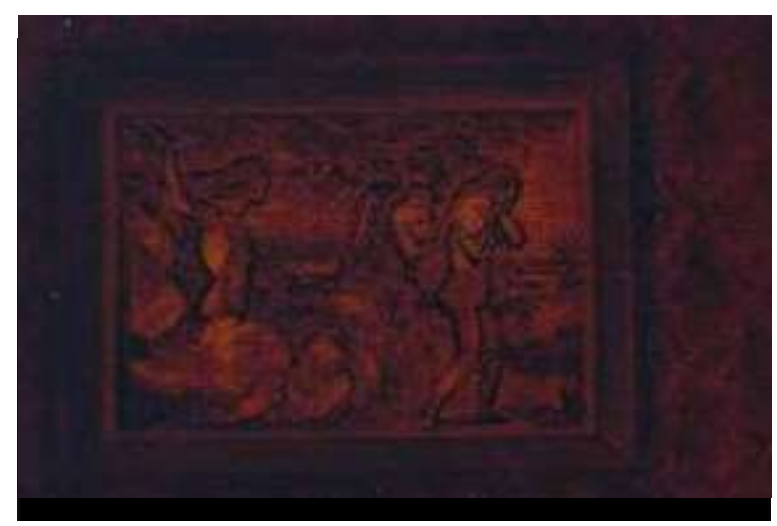

Picture 2: The Fall

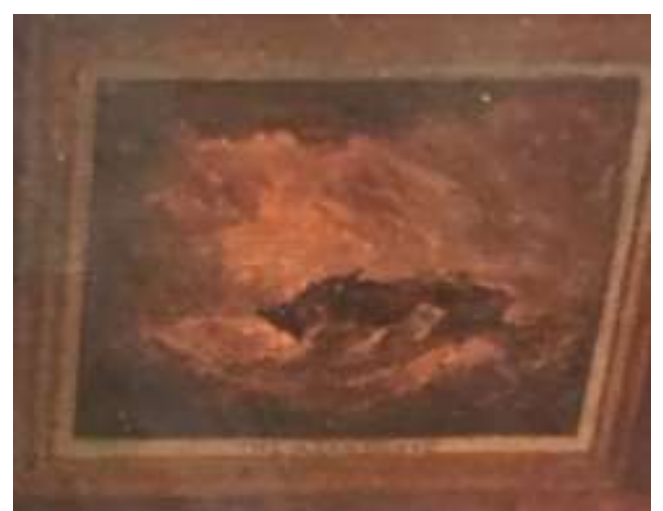

Picture 3: Clarkson Stanfield's Abandoned

17) Find symbols that prefigure the wife's future.

18) Please, explain what do you feel about the woman?

19) Please, explain what do you feel about the man?

20) Please, explain what do you feel about the children?

21) How does this situation and problem apply to our century?

Answers: 1) 19th century; 2) four people; 3) they are family; 4) the woman is lying on the floor; 5) the man is sitting on a chair and staring into the distance; 6 ) the girls are playing with cards; 7) the man: is disillusioned, disappointed, heartbroken, serious, sad; we cannot see the woman's face; the older sister is shocked and surprised; the younger sister is ignorant; 8) something bad has happened to the family, something has changed; 9) possible guess: they have got bad news; the woman did something 
improper; true answer: the woman betrayed her husband and her infidelity had been revealed; 10) he is holding a love letter that another man wrote to his wife; 11 ) the woman is begging for forgiveness; 12) apple; 13) two halves symbolize the husband and wife; 14) the fallen apple stands for the fallen woman = an expression for an immoral woman; 15) the second half of the apple symbolizes the husband whose heart hurts (as if he were stabbed); 16) two paintings hanging above the couple's portraits: one illustrates the first men's banishment from the Paradise after the Fall, the second depicts a ship in storm (Clarkson Stanfield's Abandoned; the marriage is in danger); bracelets round her wrists (give the impression that she is shackled); the cards are collapsing (breakdown of their marriage) 17) we can see the mirror reflection of the open door and a suitcase in the foreground = the woman has to leave her family. 18) possible student answers: I think it is unfair; she should have given one more chance; she should have been listened to; she should have stayed for a bit longer to decide what to do next; she deserves this because she betrayed her husband, etc. 19) I feel sorry for the man; I think the husband was too strict and hard-hearted; he should have thought about his children who need their mother, etc.20) I feel sorry about the children; the loss of their mother will change her whole life and affect them both mentally and emotionally; etc. 21) possible topics for further discussion: marriage rules (what can we do and cannot do in a marriage), divorce: pro vs contra; the most common reasons of divorce; possible ways of avoiding divorce; possible way of caring about marriage; cohabitation; causes of infidelity; copying with infidelity; trust; etc.

\section{Conclusion}

Visual aids have become a common and essential part of pedagogy in the last few decades: PowerPoint/Prezi presentations, videos, word cards and pictures each reinforce and help student's learning and pedagogics' teaching process. They serve as a bridge between the curriculum and the data processing of the learners' brain. Their multiple impact on particular areas of the brain has been proven scientifically: visual materials enhance social skills and learning and thinking skills such as: problem-solving, decision-making, imagination, creativity and language acquisition. As for learning English as a second language, the process of comprehending, memorizing and consciously using grammar rules require complex brainwork and cognitive skills, critical thinking, reasoning and skills of making connections. Various research has pointed out that working with visual arts is a proper and effective method of acquiring an appropriate level of cognitive skills and critical thinking. For example, Ives and Pond assert that the arts "contribute cognitive development" (Ives-Pond 1980: 335). Moreover, students decipher codes in both 'loci': symbolic references and connections in paintings and grammar symbols and links between rules in language. By getting accustomed to unveiling connections and thinking deeper, beyond and care with regard to paintings, students can become more conscious and critical of receiving and decoding grammar rules, reconsidering and justifying their proper use. In selecting visual arts, besides paintings, the teacher should select even among graffiti, photographs and advertisements. The selection of artwork should be relevant to the curriculum, age, language level and learning abilities of students. Also, as "[d]eep change takes time, patience, perseverance, understanding, and commitment" (Eutsler 2017: 41), in the future it should be one of the foci of pedagogical researches to include working with visual arts in the curriculum of English and other subjects in Slovakia. Thus, students' general knowledge and appreciation of arts would increase, and at the same time, their perspective would be widened, which would positively affect their way of thinking and learning. Due to the lack of official research results, the present paper did not purport to draw general and convincing conclusions about the effectivity of such a method in EFL education. Rather it intended to raise questions and initiate an effective discussion about the possible use of arts in (second language) education in Slovakia. 


\section{References}

- ALTER, Frances. 'Understanding the role of critical and creative thinking in Australian primary school visual arts education.' In International Art in Early Childhood Research Journal 1 (1) (2009), pp. 1-12. University of New England, Australia.

http://artinearlychildhood.org/artec/images/article/ARTEC 2009 Research Journal 1 Article 6.pdf

- BAKER, Dawn. 'Art Integration and Cognitive Development.' In Journal for Learning through the Arts. A Research Journal on Arts Integration in Schools and Communities 9(1) (2013). https://files.eric.ed.gov/fulltext/EJ1018320.pdf

- BROCK, Avis. 'Teaching Critical Thinking through Art, 3.2: Focal Point: How do you strengthen students' reasoning?' 2018. https://www.nga.gov/audio-video/teaching-critical-thinkingthrough-art.html

- CSEHIOVÁ, Agáta. 'Interdiszciplináris vonatkozások a művészeti és a zenei nevelés területén' A SJE Nemzetközi Tudományos Konferenciája - Medzinárodná vedecká konferencia UJS. "Oktatás és tudomány a XXI. század elején” - „Vzdelávanie a veda na začiatku XXI. storočia." Komárom, 2014. szeptember 16-17. - Komárno, 16.-17. september 2014.

- EUTSLER, Mark L. Developing Critical Thinking Through the Arts. Newburg, IN, 2017. https://files.eric.ed.gov/fulltext/ED577583.pdf

- FACIONE, Peter A. 'Critical Thinking: What It Is and Why It Counts.' Insight Assessment. Online Self-Instructional Professional Development Training Modules, 2020. Updated. https://www.insightassessment.com/wp-content/uploads/ia/pdf/whatwhy.pdf

- FOWLE, Fraces. 'Augustus Leopold Egg. Past and Present, No. 1.'2000. https://www.tate.org.uk/art/artworks/egg-past-and-present-no-1-n03278

- FREEDMAN Kerry. 'Recent shifts in US art education.' In Addison, Nicholas and Burgess, Lesley (eds.). Issues in Art and Design Teaching. RoutledgeFalmer, Oxon, 2003, pp. 8-18.

- HAVÉ Philippe. The Use of Art in English Language Teaching. Developing Learners' Receptive and Productive Skills by Engaging with Masterpieces from Classical to Modern Art. Luxemburg. 2013. file:///C:/Users/user/Documents/Have\%20Philippe\%20\%20The\%20Use\%20of\%20Art\%20in\%20English\%20Language\%20Teaching\%20TC.pdf

- IVES, William - POND Jeanne. 'The Arts and Cognitive Development.' The High School Journal 63 (8) (1980), pp. 335-340. University of North Carolina Press.

https://www.jstor.org/stable/40365007

- KULLBERG, Kristen. 'Teaching Critical Thinking through Art, 3.2: Focal Point: How do you strengthen students' reasoning?' 2018. https://www.nga.gov/audio-video/teaching-criticalthinking-through-art.html

- MINCEMOYER, Claudia C. 'Art - an opportunity to develop children's skills.' The Pennsylvania State University, 2016. http://bkc-odmedia.vmhost.psu.edu/documents/HO Art AnOpportunity.pdf

- SILVER, Rawley A. Developing Cognitive and Creative Skills through Art: Programs for Children with Communication Disorders or Learning Disabilities. Third Edition. Revised. 1989. https://files.eric.ed.gov/fulltext/ED410479.pdf

- PETERSON, R. 'Crossing bridges that connect the arts, cognitive development, and the brain.' In Journal for Learning through the Arts: A research journal on arts integration in schools and communities. 1(1) (2005), pp. 13-42. https://files.eric.ed.gov/fulltext/EJ1095284.pdf

- PUSKÁS, Andrea. Teaching Young Learners. A Textbook for EFL teacher Trainees. bymoon, 2018. 
- VYGOTSKY, L. 'Interaction between Learning and Development.' In Mind in Society. Cambridge, pp. 79-91. Cambridge MA: Harvard University Press, 1978.

https://innovation.umn.edu/igdi/wpcontent/uploads/sites/37/2018/08/Interaction Between Learning and Development.pdf

- ZOLCZER, Peter. 'Using Video Games as Sources for Story-based English Classes.' In: 11. International Conference of J. Selye University: Section on Language - Culture - Intercultural Relationships: Section on Language - Culture - Intercultural Relationships / Bukor József, Simon Szabolcs. - 1. vyd. - Komárno: Univerzita J. Selyeho, 2019. - ISBN 978-80-8122-331-0, online, s. 231-241. DOI 10.36007/3310.2019.231-241.

- ZOLCZER, Peter. 'The Integration of Translation and Audiovisual Media into Language Learning.' In Zborník medzinárodnej vedeckej konferencie Univerzity J. Selyeho - $2016=$ A Selye János Egyetem 2016-os "Korszerü szemlélet a tudományban és az oktatásban" Nemzetközi Tudományos Konferenciájának tanulmánykötete - Pedagógiai szekciók: "Súčasné aspekty vedy a vzdelávania" - Sekcie pedagogických vied. - Komárno: Univerzita J. Selyeho, 2016. - ISBN 97380-8122-187-3, CD-ROM, s. 446-455. 